\title{
Comparative secretome analyses of two Trichoderma reesei RUT-C30 and CL847 hypersecretory strains
}

\author{
Isabelle Herpoël-Gimbert* ${ }^{* 1,2}$, Antoine Margeot ${ }^{\dagger 3}$, Alain Dolla ${ }^{4}$ \\ Gwénaël Jan5,6, Daniel Mollée,6, Sabrina Lignon7, Hughes Mathis³, Jean- \\ Claude Sigoillot ${ }^{1,2}$, Frédéric Monot ${ }^{3}$ and Marcel Asther ${ }^{1,2}$
}

\begin{abstract}
Address: 1INRA, UMR1163, Biotechnologie des Champignons Filamenteux, F-13000 Marseille, France, ${ }^{2}$ Universités Aix-Marseille I \& II, UMR1163, BCF, F-13000 Marseille, France, ${ }^{3}$ IFP, Biotechnology Department, Avenue de Bois-Préau, 92852 Rueil-Malmaison Cedex, France, ${ }^{4}$ IMR, FRE3083 - CNRS, Institut de Biologie Structurale et Microbiologie, Chemin Joseph-Aiguier, 13402 Marseille cedex 20, France, 5INRA, UMR1253, Science et Technologie du Lait et de l'Oeuf, F-35000 Rennes, France, ${ }^{6}$ Agrocampus Rennes, UMR1253, STLO, F-35000 Rennes, France and 7 Plate-forme protéomique, Institut de Biologie structurale et Microbiologie, Chemin Joseph-Aiguier, 13402 Marseille cedex 20, France
\end{abstract}

Email: Isabelle Herpoël-Gimbert* - isabelle.gimbert@esil.univmed.fr; Antoine Margeot - Antoine.MARGEOT@ifp.fr; Alain Dolla - dolla@ibsm.cnrs-mrs.fr; Gwénaël Jan - Gwenael.Jan@rennes.inra.fr; Daniel Mollé - daniel.molle@rennes.inra.fr; Sabrina Lignon - lignon@ibsm.cnrs-mrs.fr; Hughes Mathis - Hugues.MATHIS@ifp.fr; Jean-Claude Sigoillot - jeanclaude.sigoillot@esil.univmed.fr; Frédéric Monot - Frederic.MONOT@ifp.fr; Marcel Asther - Marcel.Asther@esil.univmed.fr

* Corresponding author †Equal contributors

Published: 23 December 2008

Biotechnology for Biofuels 2008, I:18 doi:10.1186/1754-6834-I-18
Received: 7 October 2008

Accepted: 23 December 2008

This article is available from: http://www.biotechnologyforbiofuels.com/content///I/18

(c) 2008 Herpoël-Gimbert et al; licensee BioMed Central Ltd.

This is an Open Access article distributed under the terms of the Creative Commons Attribution License (http://creativecommons.org/licenses/by/2.0), which permits unrestricted use, distribution, and reproduction in any medium, provided the original work is properly cited.

\begin{abstract}
Background: Due to its capacity to produce large amounts of cellulases, Trichoderma reesei is increasingly been researched in various fields of white biotechnology, especially in biofuel production from lignocellulosic biomass. The commercial enzyme mixtures produced at industrial scales are not well characterized, and their proteinaceous components are poorly identified and quantified. The development of proteomic methods has made it possible to comprehensively overview the enzymes involved in lignocellulosic biomass degradation which are secreted under various environmental conditions.

Results: The protein composition of the secretome produced by industrial T. reesei (strain CL847) grown on a medium promoting the production of both cellulases and hemicellulases was explored using two-dimensional electrophoresis and MALDI-TOF or LC-MS/MS protein identification. A total of 22 protein species were identified. As expected, most of them are potentially involved in biomass degradation. The 2D map obtained was then used to compare the secretomes produced by CL847 and another efficient cellulolytic $T$. reesei strain, Rut-C30, the reference cellulaseoverproducing strain using lactose as carbon source and inducer of cellulases.

Conclusion: This study provides the most complete mapping of the proteins secreted by $T$. reesei to date. We report on the first use of proteomics to compare secretome composition between two cellulase-overproducing strains Rut-C30 and CL847 grown under similar conditions. Comparison of protein patterns in both strains highlighted many unexpected differences between cellulase cocktails. The results demonstrate that 2D electrophoresis is a promising tool for studying cellulase production profiles, whether for industrial characterization of an entire secretome or for a more fundamental study on cellulase expression at genome-wide scale.
\end{abstract}




\section{Background}

The filamentous cellulolytic fungus Trichoderma reesei is known to be an exceptionally efficient producer of cellulases and hemicellulases acting in synergy to degrade lignocellulosic materials. $T$. reesei produces a broad range of cellulases able to hydrolyze the $\beta-1,4$ glycosidic bonds present in celluloses and derivatives. The glucose produced provides the fungus with a carbon source readily usable for growth. One of the main applications is the conversion of lignocellulosic biomass to biofuels, such as ethanol [1]. Due to their biotechnological interest, the most abundant hydrolytic enzymes of $T$. reesei have been the subject of extensive structural [2-6] and genetic studies (see reviews $[7,8])$. These enzymes include two cellobiohydrolases (Cel7A and Cel6A, E.C. 3.2.1.91) that act like exoenzymes, releasing cellobiose from crystalline cellulose as the main product, five endoglucanases (Cel7B, Cel5A, Cel12A, Cel61A and Cel45A, EC 3.2.1.4) that attack cellulose in an endo-acting manner with a strong affinity towards the soluble derivatives of cellulose, and two $\beta$-glucosidases (BGLI and BGLII, EC 3.2.1.21) that cleave cellobiose to glucose [9]. The hemicellulolytic system of $T$. reese $i$ is composed of several enzymes, including endo-1,4- $\beta$-xylanases (XYNI, 2, 3 and 4, EC 3.2.1.8), mannanase (MANI, EC 3.2.1.78), acetylxylan esterase (AXEI, EC 3.1.1.72), $\alpha$-galactosidase (BGAI, EC 3.2.1.22) and arabinofuranosidase (ABFI, EC 3.2.1.55) [10-12]. In addition, new biomass degradation-related genes have been identified through cDNA sequencing and DNA microarrays $[13,14]$.

Cellulases are produced industrially using T. reesei strains genetically modified by random mutagenesis or by targeted genetic modifications such as introducing strong inducible promoters, increasing the gene copy numbers or removing undesired secreted proteins [15]. Industrial mutant strain CL847 yields a high production (about $40 \mathrm{~g}$ $\mathrm{L}^{-1}$ ) of proteins secreted in the extracellular medium $[16,17]$. Commercial cellulolytic products are generally poorly characterized enzyme mixtures containing cellulases and other unidentified proteins. The sole 2D maps of $T$. reesei secretomes reported in the literature were established from commercial cellulase preparations prior to the availability of genome sequences $[18,19]$, making it difficult to identify new enzymes. The recent ongoing sequencing of the T. reesei QM6a strain genome available from the DOE Joint Genome Institute http://genome.jgipsf.org/Trire2/Trire2.home.html gives an opportunity to gain a better understanding of the variety of enzymes secreted by this fungus.

We performed a proteomic study of the enzymes secreted from $T$. reesei CL847, which is a strain already used at industrial scale, grown under conditions promoting the production of both cellulases and hemicellulases, using
2D electrophoresis (2DE) gels coupled with MALDI-TOF and LC-MS/MS mass spectrometry. The 2D map obtained was used to compare the secretome composition of CL847 with that of the well-known cellulase overproducer Rut-C30 [20] under cellulolytic enzyme secretion-promoting conditions.

\section{Methods \\ Fungal strain and culture conditions}

For storage, T. reesei strains CL847 [21] and Rut-C30 (ATCC 56765) cultures were grown on plates of Potato Dextrose Agar (Difco Laboratories, USA) at $30^{\circ} \mathrm{C}$. After sporulation, the spores were resuspended in a sterile $\mathrm{NaCl}$ $\left(9 \mathrm{~g} \mathrm{~L}^{-1}\right)$-glycerol $20 \%$ solution and stored at $-80^{\circ} \mathrm{C}$. Frozen spores were used to inoculate a Fernbach flask containing $250 \mathrm{~mL}$ of culture medium (glucose $30 \mathrm{~g} \mathrm{~L}^{-1}$; corn steep $2 \mathrm{~g} \mathrm{~L}^{-1} ;\left(\mathrm{NH}_{4}\right)_{2} \mathrm{SO}_{4} 1.4 \mathrm{~g} \mathrm{~L}^{-1} ; \mathrm{KOH} 0.8 \mathrm{~g} \mathrm{~L}^{-1} ; \mathrm{H}_{3} \mathrm{PO}_{4}$ $85 \% 4 \mathrm{~mL} \mathrm{~L}^{-1}$; phthalic acid, dipotassium salt $5 \mathrm{~g} \mathrm{~L}^{-1}$; $\mathrm{MgSO}_{4} .7 \mathrm{H}_{2} \mathrm{O} 0.3 \mathrm{~g} \mathrm{~L}^{-1} ; \mathrm{CaCl}_{2} 0.3 \mathrm{~g} \mathrm{~L}^{-1} ; \mathrm{FeSO}_{4} .7 \mathrm{H}_{2} \mathrm{O} 5.0$ $\mathrm{mg} \mathrm{L}^{-1} ; \mathrm{MnSO}_{4} \cdot \mathrm{H}_{2} \mathrm{O} 1.6 \mathrm{mg} \mathrm{L}^{-1} ; \mathrm{ZnSO}_{4} .7 \mathrm{H}_{2} \mathrm{O} 1.4 \mathrm{mg} \mathrm{L}^{-1}$; $\mathrm{CoCl}_{2} \cdot 6 \mathrm{H}_{2} \mathrm{O} 2.0 \mathrm{mg} \mathrm{L}^{-1}$ ). Cultivation was carried out at $30^{\circ} \mathrm{C}$ with stirring at $110 \mathrm{rpm}$. After $72 \mathrm{~h}, 100 \mathrm{~mL}$ of medium broth was used as an inoculum for bioreactor culture. Fermentation of T. reesei was carried out in a $4 \mathrm{~L}$ bioreactor under culture conditions previously described by Pourquié and Warzywoda, 1993 [17]. The cellulase production was performed in two steps. In the first step, a growth phase, with $2 \mathrm{~L}$ starting medium containing $35 \mathrm{~g}$ $\mathrm{L}^{-1}$ of lactose as carbon source, $27^{\circ} \mathrm{C}$ and $\mathrm{pH}$ regulated at 4.8 (with $6 \mathrm{M}$ ammonia) was conducted. The air flow was adjusted at $0.5 \mathrm{VVM}$ and initial stirring was set at $500 \mathrm{rpm}$. This parameter was gradually increased to maintain $\mathrm{pO}_{2}$ above $40 \%$ oxygen saturation. In the second step, when initial lactose was depleted, a fed-batch phase was initiated. During this phase, a $250 \mathrm{~g} \mathrm{~L}^{-1}$ carbon source solution was injected at a $4 \mathrm{~mL} \mathrm{~h}^{-1}$ rate. The feeding solution composed of either $60 \%$ lactose and $40 \%$ xylose (W/V) or only lactose. Samples were collected periodically to determine the biomass, carbon and protein concentrations. For both strains, the initial lactose was depleted after $30 \mathrm{~h}$ of cultivation. At this stage of the culture, the biomass dry weight concentrations were between 15 to $18 \mathrm{~g} \mathrm{~L}^{-1}$ and remained steady during the whole fed-batch phase for all cultures whatever conditions were tested. No carbon source accumulation was observed during the whole fed-batch phase.

CL847 strain cultivations were performed in triplicate for the lactose as the only carbon source condition, and in duplicate for the mixed lactose-xylose condition. Only one production was carried out for the Rut-C30 strain.

\section{Analytical methods}

Lactose was assayed by high-performance liquid chromatography on a $7.8 \times 300 \mathrm{~mm}^{2} \mathrm{HPX}-87 \mathrm{P}$ column (Biorad) maintained at $85^{\circ} \mathrm{C}$, using a Varian Prostar Model 350 
HPLC equipped with a refractive index detector. Eluant was helium-degassed distilled water at a flow rate of 0.4 $\mathrm{mL} \mathrm{min}^{-1}$. Quantification was performed using a solution of $1 \mathrm{~g} \mathrm{~L}^{-1}$ of lactose as external standard.

Biomass concentration was assayed using a gravimetric method. A culture volume is filtered with a vacuum pump on a dried and preweighed $\mathrm{GF} / \mathrm{C}$ glass fiber membrane (Wathman). After washing with distilled water, membranes are dried for $48 \mathrm{~h}$ at $105^{\circ} \mathrm{C}$ and weighed.

\section{Protein extract preparation}

Samples were collected around $160 \mathrm{~h}$ after start of cultivation. At this stage, protein concentration for all cultures was around $30 \mathrm{~g} \mathrm{~L}^{-1}$. The culture supernatants were harvested by centrifugation for $15 \mathrm{~min}$ at $10,800 \mathrm{~g}$ and $4{ }^{\circ} \mathrm{C}$. The supernatants were further clarified on a glass fiber filter GF/F (Whatman, Maidstone, UK) and concentrated and diafiltered against 10 times their volumes of Milli-Q water using a $5 \mathrm{kDa}$ membrane (Amicon system, Millipore Bradford, USA) to eliminate salts. Total protein concentrations were determined in duplicates using the BioRad Dc protein assay kit (Bio-Rad). Aliquots of extracellular protein samples were stored at $-80^{\circ} \mathrm{C}$ for $2 \mathrm{DE}$ gel experiments. The same amount of proteins $(200 \mu \mathrm{g})$ was used for each 2D gel, regardless for the initial supernatant concentration.

\section{Protein separation by 2D gel electrophoresis}

Immobiline DryStrips (18 cm, pH 4-7, Amersham Biosciences) were rehydrated overnight at room temperature with $200 \mu \mathrm{g}$ of proteins diluted in rehydration solution (DeStreak solution, Amersham Biosciences) supplemented with $2 \%(\mathrm{v} / \mathrm{v})$ 4-7 IPG buffer and $2.8 \mathrm{mg} \mathrm{mL}^{-1}$ dithiothreitol to a final volume of $350 \mu \mathrm{L}$. Isoelectric focusing was performed on a Multiphor II system at $20^{\circ} \mathrm{C}$ with a 3-phase gradient program: $500 \mathrm{~V}$ for $1 \mathrm{Vh}, 3500 \mathrm{~V}$ for $3 \mathrm{kVh}$ and $3500 \mathrm{~V}$ for $27 \mathrm{kVh}$. Following isoelectric focusing, each strip was equilibrated for $10 \mathrm{~min}$ in $10 \mathrm{~mL}$ of SDS equilibration buffer ( $50 \mathrm{mM}$ Tris- $\mathrm{HCl} \mathrm{pH} 6.8,6 \mathrm{M}$ urea, $30 \%(\mathrm{v} / \mathrm{v})$ glycerol, $1 \%(\mathrm{w} / \mathrm{v})$ SDS, a trace of bromophenol blue) containing $25 \mathrm{mM}$ dithiothreitol. A second equilibration step was then performed in the same SDS equilibration buffer containing $250 \mathrm{mM}$ iodoacetamide instead of DTT. The strips were then loaded onto $12 \%$ homogeneous acrylamide gels and sealed with $0.5 \%$ $(\mathrm{w} / \mathrm{v})$ agarose in SDS running buffer $(25 \mathrm{mM}$ Tris base, $192 \mathrm{mM}$ glycine, $0.1 \%(\mathrm{w} / \mathrm{v})$ SDS). The second dimensional separation was performed using an $\operatorname{Ettan}^{\mathrm{TM}}$ DALT system (Amersham) at $0.5 \mathrm{~W} /$ gel and $16^{\circ} \mathrm{C}$ overnight, followed by $17 \mathrm{~W} /$ gel for $3 \mathrm{~h}$. After electrophoresis, the acrylamide gels were either silver-stained for spot picking experiments or stained with Biosafe Coomassie Stain (Biorad) for comparative analysis experiments.

\section{Protein identification}

\section{MALDI-TOF mass spectrometry}

For protein identification, protein spots were picked up from the gel and silver-stained spots were washed with sodium thiosulfate/potassium ferricyanide, as previously described [22]. All spots were washed, digested by trypsin, extracted and dried as previously described [23]. Spectra were acquired on a MALDI-TOF mass spectrometry Voyager DE-RP (ABI) in positive reflectron mode. Peak list was generated by DataExplorer and manually checked. Identifications were performed using GPMAW software (Lighthouse data).

\section{Liquid chromatography tandem mass spectrometry}

Spots of protein were excised from a 2D gel and subjected to in-gel tryptic digestion as above. The resulting peptides were extracted and subjected to nanoscale reverse-phase liquid chromatography on a modular LC Packings Ultimate HPLC system equipped with a Famos autosampler and a Switchos microcolumn switching device (LC Packings - a Dionex company, Amsterdam, The Netherlands). The tryptic digest samples were diluted in an aqueous solution containing $0.1 \%$ trifluoroacetic acid and preconcentrated and de-salted at a flow rate of $20 \mu \mathrm{L} \mathrm{min}{ }^{-1}$ on a $5 \mathrm{~mm} \times 300 \mu \mathrm{m}$ PepMap C18 precolumn $(100 \AA, 5 \mu \mathrm{m}$, LC Packings). The mobile phase flow from pump $\mathrm{C}$ was used to load and wash the sample for $5 \mathrm{~min}$ with an aqueous solution containing $0.1 \%$ trifluoroacetic acid and $2 \%$ acetonitrile. The peptides were then eluted onto a 150 $\mathrm{mm} \times 75 \mu \mathrm{m}$ analytical PepMap C18 column $(100 \AA$, 3 $\mu \mathrm{m}$, LC Packings). Chromatographic separation used gradient elution of $95 \%$ solution A (acetonitrile/water 2:98, $\mathrm{v} / \mathrm{v}$ ) to $50 \%$ solution B (acetonitrile/water $95: 5, \mathrm{v} / \mathrm{v}$ ), both containing $0.08 \%$ formic acid and $0.01 \%$ trifluoroacetic

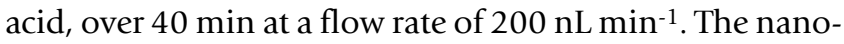
scale LC eluant from the analytical column was directed to the nanoelectrospray ionization source of a $\mathrm{QSTAR}^{\oplus} \mathrm{XL}$ global hybrid quadrupole/time-of-flight mass spectrometer (Applied Biosystems) run in positive ion mode. A voltage of approximately $2 \mathrm{kV}$ was applied to the spray needle (Picotip Emitter, 360/10 $\mu \mathrm{m}$, New Objective, MA, USA). Mass spectra were acquired with the Analyst 1.1 software using MS survey for $1 \mathrm{~s}$ followed by MS/MS for $3 \mathrm{~s}$. The instrument was calibrated with a multi-point calibration using selected fragment ions that resulted from the collision-induced decomposition (CID) of the C-terminal peptide of $\beta$-CN casein 193-209. Data-directed analysis was employed to perform MS/MS analysis on doubly and triply charged precursor ions. Product (fragmentation) ion MS/MS spectra were collected from $\mathrm{m} / \mathrm{z} 60$ to $\mathrm{m} / \mathrm{z}$ 2000. Raw data were automatically analyzed on a local server hosting Mascot V.2.1.03.

The T. reesei genome database http://www.jgi.doe.gov/ sequencing/why/2998.html was used to identify proteins from MS/MS data. 


\section{Image analysis}

For comparative studies, each culture sample was independently prepared and used in 2DE in triplicates. To allow an unbiased comparative analysis, Coomassie Blue staining was used instead of silver staining (Biosafe Coomassie Stain, Biorad). The amount of proteins used for 2DE $(200 \mu \mathrm{g})$ and Coomassie Blue staining was the best compromise between spot-detection sensibility and coloration saturation (data not shown).

Each sample was analyzed in triplicate. Gels were scanned on a calibrated GS800 scanner (Biorad). Images were analyzed using ImageMaster II software (GE Healthcare) using the following workflow. After automatic spot detection, artifacts such as dust or cracks on gels were manually eliminated, and then the weaker spots (individually < $0.05 \%$ of the whole gel volume) were eliminated. Remaining spots were then automatically linked to reference spots on a synthetic reference gel to allow comparison between samples.

\section{Enzymatic assays}

All samples were analyzed in duplicate and mean values were calculated. Overall cellulase activity of the samples was measured as Filter Paper (FP) activities using the IUPAC-recommended procedure [24]. Endoglucanase activity was assayed as CMCase activity with $\mathrm{CMC}$ (Aqualon) as substrate in $50 \mathrm{mM}$ acetate buffer (pH 4.8) for $30 \mathrm{~min}$ at $50^{\circ} \mathrm{C}$. Xylanase activity was measured with Oat Spelt Xylan (Sigma) as substrate in the same conditions. For all three activities, sugar release was assayed via the dinitrosalicylic acid method using glucose or xylose as the standard. $\beta$-glucosidase activities were determined using 4-nitrophenyl- $\beta$-D-glucopyranoside with paranitrophenol as the standard [25].

\section{Results and discussion}

\section{D mapping of T. Reesei CL847 secretome}

Cellulase and hemicellulase production is dependent on fungus cultivation conditions [26]. It has been demonstrated that the production of the main cellulases of Trichoderma is transcriptionally regulated and carbon sourcedependent $[8,13]$. In order to obtain the fullest complement of the hemicellulolytic enzymatic system, T. reesei was grown under conditions promoting the production of both cellulases and hemicellulases. Thus, T. reesei was cultivated on a lactose-xylose medium in fed-batch fermentation, since this medium is known to induce the production of both cellulases and hemicellulases in T. reesei $[27,28]$.

Total extracellular proteins from the culture supernatant were separated by 2DE. Preliminary investigations using pH 3 to 10 IPG strips revealed that most proteins had pIs $<7$. Thus, IPG strips ranging from $\mathrm{pH} 4$ to 7 were chosen for detailed expression analyses to improve the resolution of the proteins spots and facilitate further quantification of individual protein species. The resulting protein maps are shown in Figure 1. Ninety-five distinct protein spots were detected on the $2 \mathrm{D}$ gel after staining. The distribution of the protein spots showed that most strongly secreted proteins had an isoelectric point below 6 and a molecular weight above $43 \mathrm{kDa}$.

Among the 95 protein spots, 36 were identified by MALDI-TOF mass spectrometry (Table 1). To increase the amount of identified proteins, 18 additional spots were analyzed by nanoLC-MS-MS, resulting in the identification of nine further proteins (Table 2). Absence of reliable identification of the remaining protein spots is due to small amounts of biological material and/or post-translational modifications known to affect identification [18]. In most cases, molecular masses observed on $2 \mathrm{D}$ gels were higher than the expected masses calculated from the protein sequences, probably because of glycosylation. Several protein spots were assigned to the same protein, suggesting the presence of numerous isoforms and/or degraded forms (Tables 1 and 2).

As expected, most of the identified proteins were related to biomass degradation and were assigned to cellulases and hemicellulases. Cellobiohydrolases Cel7A and Cel6A were the two most abundantly secreted proteins. These proteins are known to account for 70 to $80 \%$ of the total $T$. reesei cellulases $[4,29]$, consistent with the high intensity of the corresponding protein spots observed on the gel. The only $\beta$-glucosidase identified on the gel was BGLI, in accordance with reports of the other $\beta$-glucosidases being either intra-cellular, membrane-anchored, or playing only a minor role in cellulose hydrolysis [6]. Four out of the five known endoglucanases were also identified, but one of them, endoglucanase Cel61A, was only identified with a single peptide and thus should be considered provisional (Table 2). The minor endoglucanase Cel45A of $T$. reesei [30] was not identified, probably because of its highly acidic pI. This secretome analysis also revealed the expression of the ORF_27554 product annotated as candidate endoglucanase in the $T$. reesei genome database. The similarity between the observed and predicted molecular weight for this new endoglucanase (Table 1) suggests that this protein is only sparsely glycosylated. In addition, the product of the gene cel74a [6] was detected on the protein map. This enzyme, formerly endoglucanase VI, has been characterized as a xyloglucanase. The observation that several spots matched to this protein supports previous data that there are multiple isoforms of this enzyme [31].

We also identified some major components of the hemicellulolytic system of $T$. reesei: $\beta$-xylosidases, xylanases and arabinofuranosidase (Table 1). Three out of the four 
4 $\mathrm{pH}$ 7

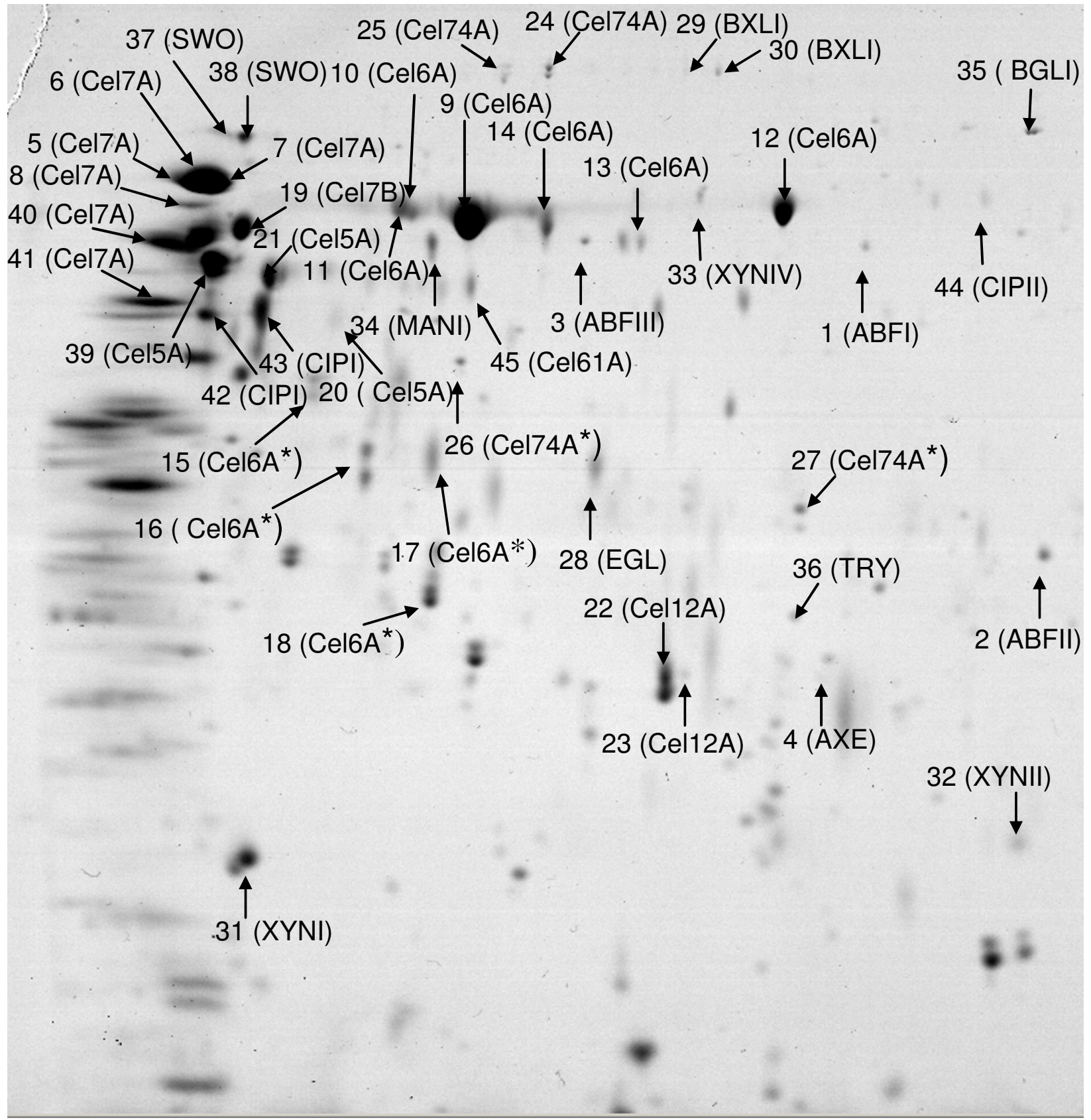

Figure I

Coomassie blue-stained 2DE gel of secreted proteins from T. reesei CL847 cultivated on xylose-lactose medium. The protein spots identified are labeled by the protein abbreviations given in Tables I and 2 . Spots names with asterisks refer to degraded form of proteins.

known xylanases were identified. The last xylanase, XYNIII, focalizes at a $\mathrm{pH}$ around 8 and is outside the range of our $\mathrm{pH} 4$ to 7 gels (data not shown). Furthermore, we did not identify any galactosidases, which is surprising given that these proteins are purported to be induced by lactose [32]. It is not unlikely that this protein corre- 
Table I: Identification of the protein-spots by MALDI-TOF mass spectrometry.

\begin{tabular}{|c|c|c|c|c|c|c|}
\hline Spot number & Locus $^{\mathrm{a}}$ & Protein name & Predb MW/pl & Exptc MW/pl & GPMAW Optimised Score & $\%$ sequence coverage \\
\hline 1 & ORF_123283 & Arabinofuranosidase (ABFI) & $51.1 / 6.0$ & $53 / 6.3$ & 432 & 38 \\
\hline 2 & ORF_76210 & Arabinofuranosidase (ABFII) & $34.8 / 6.4$ & $33 / 6.7$ & 176 & 34 \\
\hline 3 & ORF_55319 & Arabinofuranosidase (ABFIII) & $53.1 / 5.7$ & $55 / 5.5$ & 168 & 16 \\
\hline 4 & ORF_54219 & $\begin{array}{c}\text { Candidate acetyl xylan esterase } \\
\text { (AXE) }\end{array}$ & $21.9 / 6.2$ & $27 / 6.2$ & 222 & 19 \\
\hline 5 & ORF_123989 & Cellobiohydrolase I (Cel7A) & $54.1 / 4.6$ & $63 / 4.5$ & 80 & 7 \\
\hline 6 & ORF_123989 & Cellobiohydrolase I (Cel7A) & $54.1 / 4.6$ & $63 / 4.4$ & 64 & 8,8 \\
\hline 7 & ORF_I23989 & Cellobiohydrolase I (Cel7A) & $54.1 / 4.6$ & $63 / 4.6$ & 86 & 9 \\
\hline 8 & ORF_123989 & Cellobiohydrolase I (Cel7A) & $54.1 / 4.6$ & $57 / 4.7$ & 107 & 13 \\
\hline 9 & ORF_72567 & Cellobiohydrolase II (Cel6A) & $49.6 / 5.1$ & $56 / 5.2$ & 210 & 24 \\
\hline 10 & ORF_72567 & Cellobiohydrolase II (Cel6A) & $49.6 / 5.1$ & $58 / 5.0$ & 153 & 11 \\
\hline 11 & ORF_72567 & Cellobiohydrolase II (Cel6A) & $49.6 / 5.1$ & $59 / 4.8$ & 207 & 18 \\
\hline 12 & ORF_72567 & Cellobiohydrolase II (Cel6A) & $49.6 / 5.1$ & $58 / 6.0$ & 165 & 17 \\
\hline 13 & ORF_72567 & Cellobiohydrolase II (Cel6A) & $49.6 / 5.1$ & $55 / 5.6$ & 125 & 11 \\
\hline 14 & ORF_72567 & Cellobiohydrolase II (Cel6A) & $49.6 / 5.1$ & $55 / 5.4$ & 77 & 4 \\
\hline 15 & ORF_72567 & Cellobiohydrolase II (Cel6A) & $49.6 / 5.1$ & $42 / 4.7$ & 157 & 20 \\
\hline 16 & ORF_72567 & Cellobiohydrolase II (Cel6A) & $49.6 / 5.1$ & $38 / 4.9$ & 279 & 17 \\
\hline 17 & ORF_72567 & Cellobiohydrolase II (Cel6A) & $49.6 / 5.1$ & $38 / 5.0$ & 307 & 20 \\
\hline 18 & ORF_72567 & Cellobiohydrolase II (Cel6A) & $49.6 / 5.1$ & $30 / 5.1$ & 279 & 17 \\
\hline 19 & ORF_I2208I & Endoglucanase I (Cel7B) & $48.2 / 4.7$ & $55 / 4.6$ & 57 & 9 \\
\hline 20 & ORF_120312 & Endoglucanase II (Cel5A) & $44.1 / 5.0$ & $43 / 4.8$ & 160 & 31 \\
\hline 21 & ORF_I20312 & Endoglucanase II (Cel5A) & $44.1 / 5.0$ & $48 / 4.6$ & 64 & 12 \\
\hline 22 & ORF_I23232 & Endoglucanase III (CelI2A) & $25.1 / 6.7$ & $25 / 5.7$ & 185 & 19 \\
\hline 23 & ORF_I23232 & Endoglucanase III (Cel/2A) & $25.1 / 6.7$ & $26 / 57$ & 185 & 19 \\
\hline 24 & ORF_4908I & Xyloglucanase (Cel74A) & $87.1 / 5.4$ & $96 / 5.4$ & 201 & 16 \\
\hline 25 & ORF_4908I & Xyloglucanase (Cel74A) & $36.2 / 8.7$ & $96 / 5.3$ & 520 & 26 \\
\hline 26 & ORF_4908I & Xyloglucanase (Cel74A) & $36.2 / 8.7$ & $43 / 5.2$ & 406 & 21 \\
\hline 27 & ORF_4908I & Xyloglucanase (Cel74a) & $36.2 / 8.7$ & $35 / 6.0$ & 354 & 12 \\
\hline 28 & ORF_27554 & Candidate Endoglucanase (EGL) & $36.2 / 8.7$ & $36 / 5.5$ & 87 & 15 \\
\hline 29 & ORF_121127 & Xylosidase I (BXLI) & $87.2 / 5.5$ & $97 / 5.6$ & 208 & 12 \\
\hline 30 & ORF_I2II 27 & Xylosidase I (BXLI) & $87.2 / 5.5$ & $97 / 5.7$ & 203 & 15 \\
\hline 31 & ORF_74223 & Xylanase I (XYNI) & $24.6 / 5.0$ & $21 / 4.6$ & 85 & 16 \\
\hline 32 & ORF_I23818 & Xylanase II (XYNII) & $24.1 / 7.9$ & $21 / 6.6$ & 212 & 27 \\
\hline 33 & ORF_IIII849 & Xylanase IV (XYNIV) & $52.8 / 5.7$ & $55 / 5.6$ & 125 & 13 \\
\hline 34 & ORF_56996 & Mannanase I (MANI) & $40.2 / 5.1$ & $53 / 5.1$ & 147 & 17 \\
\hline 35 & ORF_76672 & $\beta$-Glucosidase (BGLI) & $78.4 / 6.4$ & $81 / 6.7$ & 440 & 32 \\
\hline 36 & ORF_73897 & Trypsin-like protease (TRY) & $26.4 / 5.8$ & $29 / 6.0$ & 92 & 28 \\
\hline
\end{tabular}

a From http://genome.jgi-psf.org/Trire2/Trire2.home.html

bPredicted $M W(\mathrm{kDa})$ and $\mathrm{pl}$ according to the sequence

CExperimental MW (kDa) and pl

sponded to one of the minor unidentified spots. The present study highlights the production of a putative arabinofuranosidase (ORF_55319, ABFIII Table 1). As stated previously for the putative endoglucanase, the close correlation between the observed and predicted molecular weight of this putative arabinofuranosidase suggests that this enzyme is also sparsely glycosylated. T. reese $i$ is thus able to produce at least three different arabinofuranosidases. Two of them have already been described in a purification study (ABFI) [33] and in cDNA analysis (ABFII) [13]. This work provides evidence for the production of both ABFII and a novel third $\alpha$-L-arabinofuranosidase (ORF_55319, ABFIII) not reported previously. Apart from cellulases and hemicellulases, non-hydrolytic proteins including CIPI, CIPII and swollenin were identified
(Table 2), providing new evidence for the production and secretion of these proteins. CIPI and CIPII were discovered during the $T$. reesei genome sequencing program as proteins with a cellulose-binding domain, but no other functional domain, such as a glycosyl hydrolase domain, could be found [13]. However, a recent phylogenetic analysis suggests they share close relationships with cellulases, which adds support to the potential roles of these genes in biomass degradation [14]. Proteolytic enzymes such as trypsin were also found at low levels $(0.2 \%)$. This may explain the presence of some altered proteins, especially Cel6A, whose molecular weight in the gels was lower than expected (Figure 1). Heterogeneity of cellobiohydrolases on PAGE-SDS has already been reported, and explained by glycosylation and proteolysis [19]. 
Table 2: Identification of the protein-spots by Nano-LC MSMS mass spectrometry.

\begin{tabular}{|c|c|c|c|c|c|c|c|}
\hline Spot number & Locus $^{\mathrm{a}}$ & Protein name & Predb $\mathrm{MW} / \mathrm{pl}$ & Exptc MW/pl & $\begin{array}{c}\text { Number of peptides } \\
\text { matched }\end{array}$ & Global Score & $\begin{array}{l}\text { \% sequence } \\
\text { coverage }\end{array}$ \\
\hline 37 & ORF_123992 & Swollenin (SWO) & $51.5 / 4.8$ & $80 / 4.6$ & 8 & 296 & 20.3 \\
\hline 38 & ORF_I23992 & Swollenin (SWO) & $51.5 / 4.8$ & $80 / 4.7$ & 6 & 252 & 20.3 \\
\hline 19 & ORF_I22008I & $\begin{array}{c}\text { Endoglucanase I } \\
\text { (Cel7B) }\end{array}$ & $48.2 / 4.7$ & $55 / 4.6$ & 13 & 477 & 31.6 \\
\hline 39 & ORF_I20312 & $\begin{array}{c}\text { Endoglucanase II } \\
\text { (Cel5A) }\end{array}$ & $44.1 / 5.0$ & $50 / 4.5$ & 9 & 181 & 32.3 \\
\hline 21 & ORF_I20312 & $\begin{array}{c}\text { Endoglucanase II } \\
\text { (Cel5A) }\end{array}$ & $44.1 / 5.0$ & $48 / 4.6$ & 13 & 451 & 39.5 \\
\hline 40 & ORF_I23989 & $\begin{array}{c}\text { Cellobiohydrolase I } \\
\text { (Cel7A) }\end{array}$ & $54.1 / 4.6$ & $55 / 4.4$ & 4 & 114 & 10.1 \\
\hline 41 & ORF_I23989 & $\begin{array}{c}\text { Cellobiohydrolase I } \\
(\text { Cel7A })\end{array}$ & $54.1 / 4.6$ & $47 / 4.4$ & 2 & 65 & 3.1 \\
\hline 42 & ORF_73638 & $\begin{array}{l}\text { Cellulose binding } \\
\text { protein (CIPI) }\end{array}$ & $32.9 / 4.9$ & $43 / 4.6$ & 5 & $|7|$ & II.I \\
\hline 43 & ORF_73638 & $\begin{array}{l}\text { Cellulose binding } \\
\text { protein (CIPI) }\end{array}$ & $32.9 / 4.9$ & $47 / 4.5$ & 9 & 250 & 39.9 \\
\hline 44 & ORF_I23940 & $\begin{array}{l}\text { Cellulose binding } \\
\text { protein (CIPII) }\end{array}$ & $48.3 / 7.0$ & $57 / 6.6$ & 7 & 281 & 15.2 \\
\hline 45 & ORF_73643 & $\begin{array}{c}\text { Endoglucanase IV } \\
\text { (Cel6IA) }\end{array}$ & $35.5 / 5.3$ & $47 / 5.2$ & 1 & $36^{d}$ & 3.8 \\
\hline
\end{tabular}

a From http://genome.jgi-psf.org/Trire2/Trire2.home.html

bPredicted $M W(\mathrm{kDa})$ and $\mathrm{pl}$ according to the sequence

CExperimental MW $(\mathrm{kDa})$ and $\mathrm{pl}$

dIndividual peptide scores $>26$ indicate identity or extensive homology $(p>0.05)$

In total, 22 biomass-degrading enzymes were identified on our gels, to be compared with the previous study of Vinzant et al (2001) [19] where only 10 enzymes were identified. An analysis of the lactose-xylose 2D gel image by ImageMaster II software indicated that the identified proteins account for $83 \%$ of all visible proteins in the gel in terms of spot volume. This percentage rises to $93 \%$ for the secretome of $T$. reesei CL847 grown on lactose alone.

\section{Comparison between secretomes of CL847 and Rut-C30 produced on lactose}

Rut-C30 has for decades been the reference cellulase-overproducing strain in academic publications. This strain, like CL847, has been obtained through random mutagenesis and subsequent screening. The last common ancestor of these two strains is the reference T. reesei strain QM6a.
CL847 was further evolved from strain QM9414. Enzymatic activities vary significantly between these two strains (Table 3). In the same culture conditions, Rut-C30 has a slightly higher FPase and CMCase-specific activity, while xylanase and $\beta$-glucosidase activities are significantly higher for CL847 strain (respectively $\times 2.7$ and $\times 1.5$ ). Two mutations were identified in Rut-C30. Firstly, a mutation in cre1, a gene encoding a transcription factor mediating glucose repression for cellulase production was discovered. This frameshift mutation leads to a truncated protein that might account for some increase in cellulase production in this strain [34]. Secondly, a frameshift mutation was observed for glucosidase II alpha subunit, leading to defective extracellular protein glycosylation [35]. However, it is almost certain that these are not the only mutations affecting this strain. As Rut-C30 grown on

Table 3: Routinely obtained specific activities for cellulase preparations used in present work.

\begin{tabular}{lllll}
\hline & $\begin{array}{l}\text { FPase } \\
\mu \mathrm{mol} \text { glucose/min/mg prot }\end{array}$ & $\begin{array}{l}\text { CMCase } \\
\mu \mathrm{mol} \text { glucose/min/mg prot }\end{array}$ & $\begin{array}{l}\text { Xylanase } \\
\mu \mathrm{mol} \text { xylose/min/mg prot }\end{array}$ & $\begin{array}{l}\beta-\text { glucosidase } \\
\mu \mathrm{mol} \text { PNP/min/mg prot }\end{array}$ \\
\hline CL847 Lact-Xyl & $0.36( \pm 0.02)$ & $0.53( \pm 0.06)$ & $55( \pm 5.5)$ & $1121( \pm 6)$ \\
\hline CL847 Lact & $0.39( \pm 0.025)$ & $0.46( \pm 0.01)$ & $34( \pm 1.5)$ & $13919( \pm 373)$ \\
\hline Rut-C30 Lact & $0.43( \pm 0.009)$ & $0.58( \pm 0.05)$ & $12.5( \pm 0.8)$ & $9019( \pm 96)$ \\
\hline
\end{tabular}

Numbers in brackets are standard deviations obtained for the same preparation with duplicates. 'Lact' stands for production induced with Lactose alone while 'Lact-Xyl' stands for production induced with mixed lactose and xylose (see Methods section). FPase stands for Filter Paper activity and CMCase stands for activity on Carboxy-methyl-cellulose. 
lactose and xylose failed to produce cellulases, secretomes of Rut-C30 and CL847 were produced with lactose as the only carbon source.

As for proteome map construction, samples were taken during the late fed-batch production phase (around 160 h) for each sample. At this stage of the production, protein concentrations were around $30 \mathrm{~g} \mathrm{~L}^{-1}$ for both strains.

The 2DE profiles of CL847 and Rut-C30 grown on lactose were very different, in terms of both spot numbers and protein composition (Figure 2). CL847 2DE reveals many more protein spots that Rut-C30, especially in minor spots corresponding to less than $0.5 \%$ of total spots volume (Figure 3), and consequently most of these spots are unidentified or correspond to degradation forms absent in Rut-C30. Differences in protein spots representing a higher percentage of the total spot volume are due to the presence of several Cel7A isoforms for CL847, while a single and bigger spot is visible for Rut-C30. In contrast, Cel6A isoform profiles were similar. Protein spot quantitation revealed that Rut-C30 has 10\% more total cellobiohydrolases than CL847 (Figure 4A). This is related to a higher Cel7A level in this strain $(57.4 \%$ in Rut-C30 versus
$42.1 \%$ in CL847), since Cel6A levels were not significantly different between the two strains. As a consequence, the Cel7A-to-Cel6A ratio is much higher in Rut-C30 than in CL847 (Figure 4B). This is in disagreement with the widespread hypothesis that Cel7A and Cel6A are co-regulated $[16,36]$. Nevertheless, we cannot rule out the possibility that this change in ratio could be due to a higher level of degradation of Cel7A in CL847. In contrast with cellobiohydrolases levels, the relative amount of BGLI produced by CL847 is twice as much as compared to Rut-C30 (Figure $4 \mathrm{D}$ ), which is reflected in $\beta$-glucosidases activities for these strains in similar conditions (Table 3). No significant differences were observed for endoglucanases Cel7 B and Cel5A. However, this area of the gels is heavily crowded, especially for CL847, and any quantification must be taken with caution (Figure 2). Contrast was more pronounced for minor endoglucanases. CL847 produces around 2\% Cel12A, while it is almost undetectable in RutC30 samples. Cel61A and Cel74A levels were much higher in Rut-C30 (Figure 4C). These results contrast with those of Foreman et al (2003) [13], where endoglucanase co-expression was observed at the mRNA level, prompting the authors to propose co-regulation of these enzymes. We observed no such events at protein level, but the dif-
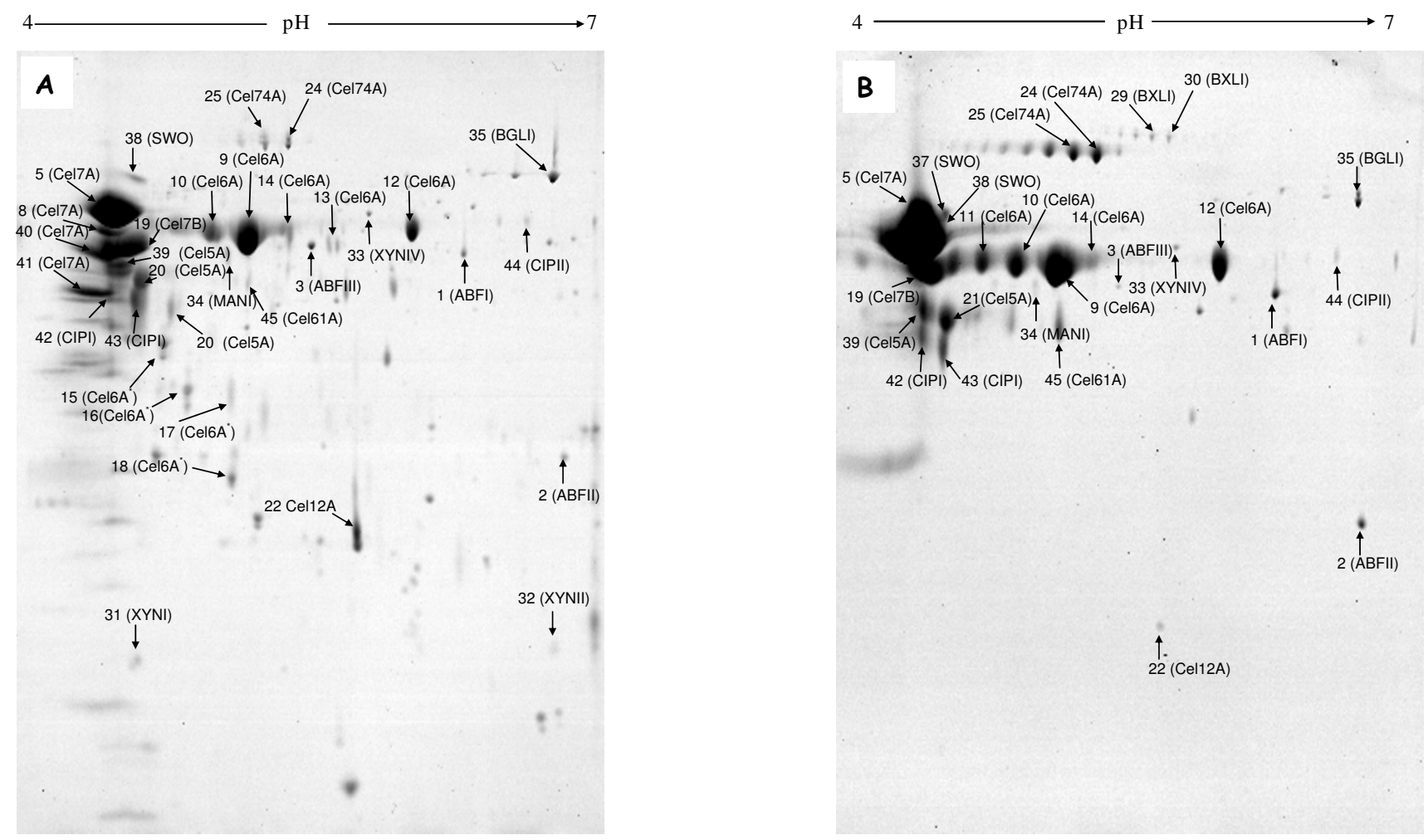

\section{Figure 2}

Coomassie blue-stained 2DE gel of secreted proteins from T. reesei CL847 (A) and Rut-C30 (B) cultivated on lactose medium. The protein spots identified are labeled by the protein abbreviations given in Tables $\mathrm{I}$ and 2 . 


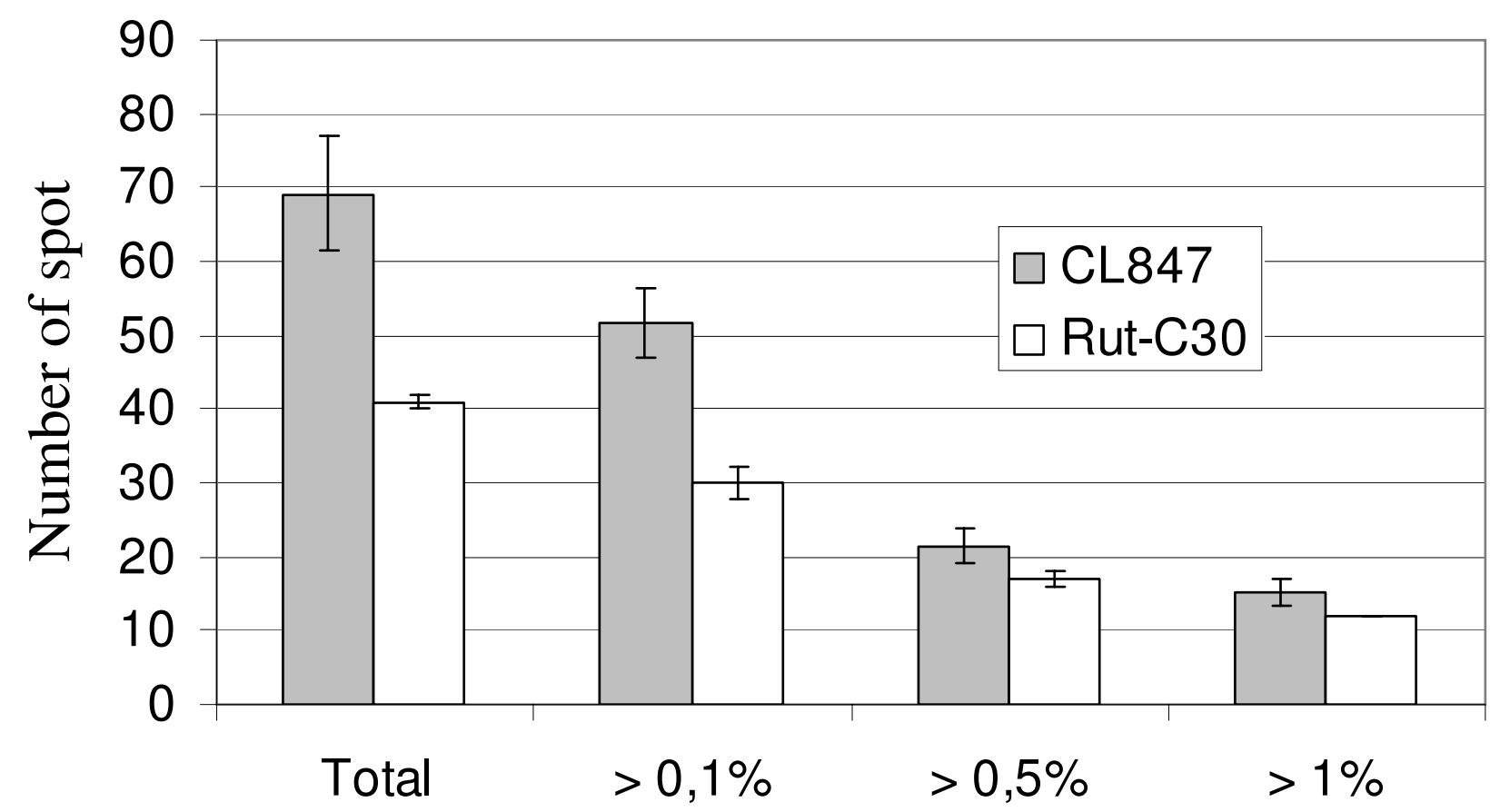

Figure 3

Spot volume distribution of Rut-C30 and CL847 secretomes. Standard deviations are calculated from three replicates. Differences between the two strains can be related to both small spots, which are more abundant in CL847, and isoforms, equally more abundant in this strain.

ferences may be due to the different strains and culture conditions used in our work and Foreman's. Another point to highlight is that the EGL and AXEIII are also absent in the both strains cultivated on lactose. The $\beta$ xylosidase, BXLI, is only present in Rut-C30, although at a very low percentage $(0.2 \%)$. This is consistent with reports of a low constitutive expression of the BXLI protein in RutC30 [10]. The only xylanase expressed in Rut-C30 was XYNIV, secreted at a similar level to CL847 (Figure 4F). In contrast, in CL847, XYNIV only figured as one of the minor xylanases. This suggests that expression of xylanases XYNI, XYNII and XYNIV is different in the two studied Trichoderma strains and that these different expression pathways were not equally affected by the mutations that led to the CL847 and Rut-C30 phenotypes. Globally, RutC30 has a lower xylan-related enzyme secretion while CL847 secretes a more diversified set of enzymes. Other hemicellulase levels also showed marked differences. While ABFII levels were comparable and ABFIII level was tenfold higher in CL847, ABFI was slightly over-produced in Rut-C30 (Figure 4E). As for xylanases, the results suggest that the role of these proteins is not equivalent and that they are not co-regulated. The only mannanase of $T$. reesei was expressed twice more in CL847 than in Rut-C30 (Figure 4E). Among non-cellulolytic enzymes, except for the absence of CIPII, there was no significant detectable difference in CIPI and SWO. Finally, trypsin was absent in Rut-C30. The presence of proteases may explain the observation of degraded forms of proteins in CL847 and the much higher number of spots, especially in the low molecular weight region of the gels.

These results fit nicely with data obtained from specific enzymatic activities (Table 3): the lower FPase activity in CL847 can be related to the lower amount of cellobiohydrolases in this strain. While it is difficult to link the CMCase activity differences to any specific protein, since many enzymes exhibit endoglucanase activity, the higher $\beta$-glucosidase and xylanase specific activities are consistent with the higher BGLI and xylanases activities in the CL847 cellulase productions (Figure 4).

\section{Conclusion}

A total of 22 extracellular protein species of $T$. reesei was identified. Most of the corresponding proteins were involved in lignocellulose degradation. In addition to the reference map of the secreted proteins, we describe hitherto unreported experimental evidence of the expression of a new putative endoglucanase and a new putative arabinofuranosidase. 

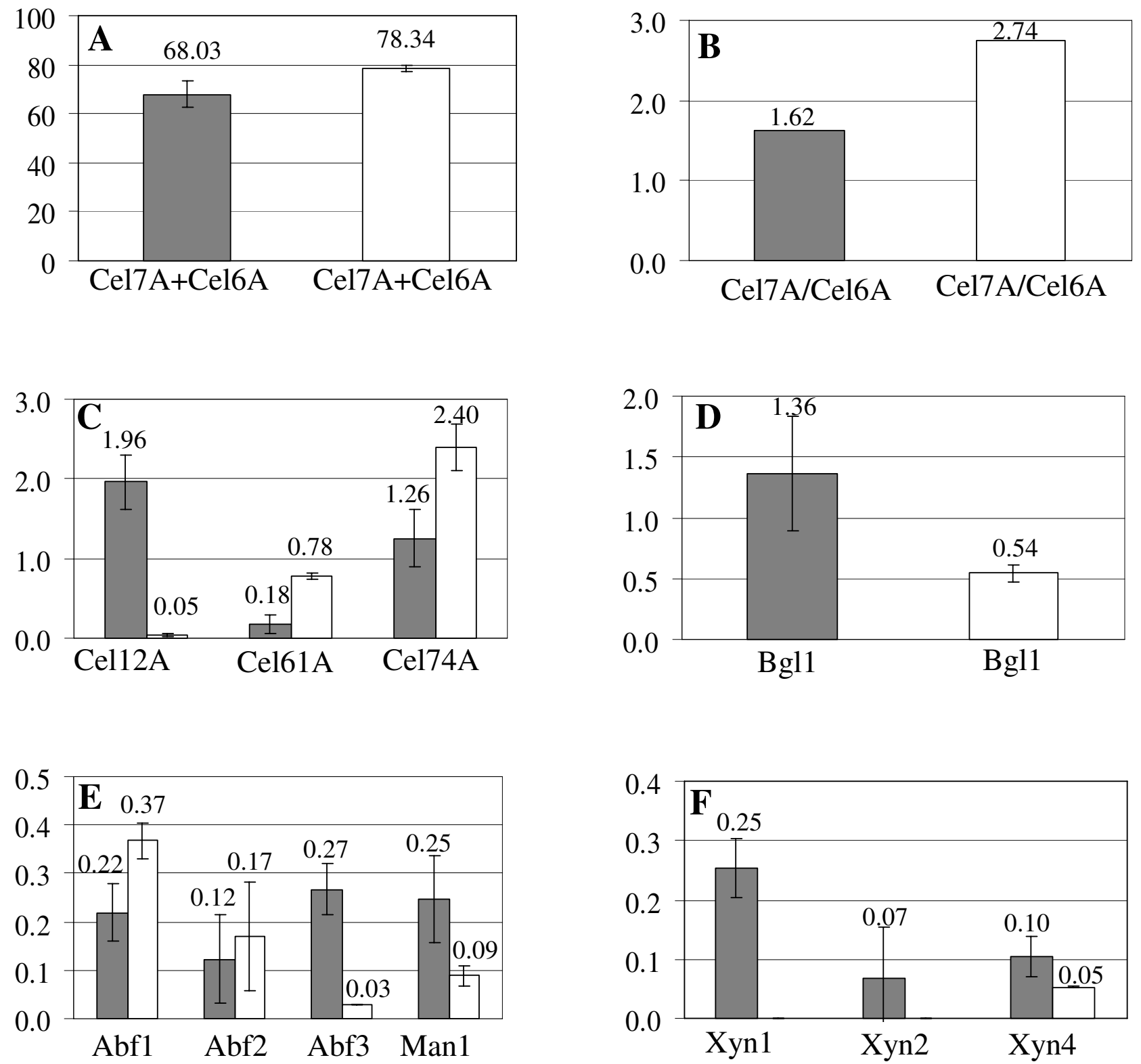

\section{Figure 4}

Comparative Analysis of Rut-C30 (white histograms) and CL847 (grey histograms) secretomes. Values are expressed in \%Volume except for B where it is a \%Cel7A/\%Cel7B ratio. A: Volume of total cellobiohudrolases; B: Cel7A-toCel6A ratio; C: Secondary endoglucanases; D: $\beta$-glucosidase; E: Non-xylolytic hemicellulases and F: Xylanases.

The last common ancestor of CL847 and Rut-C30 is the originally isolated strain QM6a. This secretome study shows that mutagenesis, in addition to improving the secretion capacities of cellulases, also seems to lead to different enzyme cocktail compositions. The more diversified secretome of CL847 suggests that this strain may be a more general hypersecretory strain while Rut-C30 may be more cellulase-oriented. It suggests that Rut-C30 and
CL847 were obtained using a totally different 'mutation route' towards becoming efficient producers. On the genetic regulation level, the only known transcription factors are the XYRI and ACEII activators and the CREI and ACEI repressors [8], all of which act at global level. Contrasts in secretome profiles, such as those observed in CL847 and Rut-C30 in this research, could potentially be attributed to chromosomal rearrangements or chromatin 
structure [35], making it particularly tricky to identify the mutations involved without extensive genomic investigation. Moreover, studying secretomes produced in different conditions for the same strains will provide greater insight into secretion behavior and cellulase regulation.

\section{Competing interests}

The authors declare that they have no competing interests.

\section{Authors' contributions}

IHG and AM carried out the 2D gel electrophoresis experiments and drafted the manuscript. $\mathrm{AD}$ analyzed the MALDI-TOF mass spectra using the GPMAW software and helped with manuscript preparation. GJ participated in the protein identification by liquid chromatography-tandem mass spectrometry and helped with manuscript preparation. DM carried out the protein identification by liquid chromatography-tandem mass spectrometry. SL performed the MALDI-TOF mass spectrometry measurements. HM performed 2D gels, image analysis and spot picking for protein identification. JCS reviewed and commented on the manuscript. FM and MA directed the overall study and drafting of the manuscript. All authors read and approved the final manuscript.

\section{Acknowledgements}

This research was supported by the French AGRICE program $\left(\mathrm{N}^{\circ}\right.$ 04.0I C.0043). We thank Patricia Skorski for the protease activity assays and Michel Warzywoda for producing the cellulases.

\section{References}

I. Lin Y, Tanaka S: Ethanol fermentation from biomass resources: current state and prospects. Appl Microbiol Biotechnol 2006, 69:627-642.

2. Rouvinen J, Bergsfors T, Teeri T, Knowles KJC: Three-dimensional structure of cellobiohydrolase II from Trichoderma reesei. Science 1990, 249:380-386.

3. Divine C, Stahlberg J, Reinikaninen T, Rouhonen L, Petterson G, Knowles KJC, Teeri T, Jones TA: The three-dimensional crystal structure of the catalytic core of cellobiohydrolase I from Trichoderma reesei. Science 1994, 265:524-528.

4. Sandgren M, Stahlberg J, Mitchinson C: Structural and biochemical studies of GH family I 2 cellulases: improved thermal stability, and ligand complexes. Prog Biophys Mol Biol 2005, 89:246-291.

5. Rojas AL, Fischer H, Eneiskaya EV, Kulminskaya AA, Shabalin KA, Neustroev KN, Craievich AF, Golubev AM, Polikarpov I: Structura insights into the beta-xylosidase from Trichoderma reese obtained by synchrotron small-angle $X$-ray scattering and circular dichroism spectroscopy. Biochemistry 2005 , 44:15578- 15584

6. Shallom D, Shoham Y: Microbial hemicellulases. Curr Opin Microbiol 2003, 6:219-223.

7. Schmoll M, Kubicek CP: Regulation of Trichoderma cellulase formation: lessons in molecular biology from an industrial fungus. A review. Acta Microbiol Immunol Hung 2003, 50: I 25-I 45.

8. Stricker AR, Mach RL, de Graaff LH: Regulation of transcription of cellulase- and hemicellulase-encoding genes in Aspergillus niger and Hypocrea jecorina (Trichoderma reesei). Appl Microbiol Biotechnol 2008, 78:21 I-220.

9. Karlsson J, Siika-aho M, Tenkanen M, Tjerneld F: Enzymatic properties of the low molecular mass endoglucanases CelI $2 \mathrm{~A}$ (EG III) and Cel45A (EG V) of Trichoderma reesei. J Biotechnol 2002, 99:63-78.
10. Margolles Clark E, Ilmen M, Penttila M: Expression patterns of ten hemicellulase genes of the filamentous fungus Trichoderma reesei on various carbon sources. J Biotechnol 1997, 57:167-179.

II. Clarkson K, Siika-Aho M, Tenkanen M, Bower B, Penttila M, Saloheimo M: Trichoderma reesei xylanase. Patent $200 \mathrm{I}$.

12. Ogasawara W, Shida Y, Furukawa T, Shimada R, Nakagawa S, Kawamura M, Yagyu T, Kosuge A, Xu J, Nogawa M, Okada H, Morikawa Y: Cloning, functional expression and promoter analysis of xylanase III gene from Trichoderma reesei. Appl Microbiol Biotechnol 2006, 72:995-1003.

13. Foreman PK, Brown D, Dankmeyer L, Dean R, Diener S, Dunn-Coleman NS, Goedegebuur F, Houfek TD, England GJ, Kelley AS, Meerman HJ, Mitchell T, Mitchinson C, Olivares HA, Teunissen PJ, Yao J, Ward $M$ : Transcriptional regulation of biomass-degrading enzymes in the filamentous fungus Trichoderma reesei. J Biol Chem 2003, 278:31988-31997.

14. Ouyang J, Yan M, Kong D, Xu L: A complete protein pattern of cellulose and hemicellulase genes in the filamentous fungus Trichoderma reesei. Biotechnol J 2006, I: I 266- I 274

I5. Nevalainen $H$, Suominen $P$, Taimisto $K$ : On the safety of Trichoderma reesei. J Biotechnol 1994, 37:193-200.

16. Durand H, Baron M, Calmels T, Tiraby G: Classical and molecular genetics applied to Trichoderma reesei for the selection of improved cellulolytic industrial strains. In Biochemistry and Genetics of cellulose degradation Edited by: Aubert J, Benguin P, Millet J. San Diego: Academic Press; 1988:I35-15I.

17. Pourquie J, Warzywoda M: Cellulase production by Trichoderma reesei. In Bioconversion of Forest and Agricultural Plant Residues Edited by: Saddler JN. Wallingford: CAB International; 1993: I07-I I6.

18. Fryksdale BG, Jedrzejewski PT, Wong DL, Gaertner AL, Miller BS: Impact of deglycosylation methods on two-dimensional gel electrophoresis and matrix assisted laser desorption/ionization- time-of-flight -mass spectrometry for proteomic analysis. Electrophoresis 2002, 23:2184-2193.

19. Vinzant TB, Adney WS, Decker SR, Baker JO, Kinter MT, Sherman NE, Fox JW, Himmel ME: Fingerprinting Trichoderma reesei hydrolases in a commercial cellulase preparation. Appl Biochem Biotechnol 2001, 91-93:99-107.

20. Eveleigh DE, Montenecourt BS: Increasing yields of extracellular enzymes. Adv Appl Microbiol 1979, 25:57-74.

21. Durand $H$, Clanet M, Tiraby G: Genetic improvement of Trichoderma reesei for large scale cellulase production. Enzyme Microbiol Technol 1988, 10:341-346.

22. Gharahdaghi F, Weinberg CR, Meagher DA, Imai BS, Mische SM: Mass spectrometric identification of proteins from silverstained polyacrylamide gel: a method for the removal of silver ions to enhance sensitivity. Electrophoresis 1999, 20:60 I-605.

23. Wilm M, Shevchenko A, Houthaeve T, Breit S, Schweigerer L, Fotsis $\mathrm{T}$, Mann M: Femtomole sequencing of proteins from polyacrylamide gels by nano-electrospray mass spectrometry. Nature 1996, 379:466-469.

24. Ghose TK: Measurement of cellulase activities. Pure Appl Chem 1987, 59:257-268.

25. Berghem LER, Petterson LG: The mechanism of enzymatic cellulose degradation. Isolation and some properties of $\beta$-glucosidase from Trichoderma viride. Eur J Biochem 1974, 46:295-305

26. Juhasz T, Szengyel Z, Reczey K, Siika-Aho M, Viikari L: Characterization of cellulases and hemicellulases produced by Trichoderma reesei on various carbon sources. Process Biochem 2005, 40:3519-3525.

27. Morikawa $\mathrm{Y}$, Ohashi $\mathrm{T}$, Mantani $\mathrm{O}$, Okada $\mathrm{H}$ : Cellulase induction by lactose in Trichoderma reesei PC-3-7. Appl Microbiol Biotechnol 1995, 44:106-III.

28. Xiong $\mathrm{H}$, Turunen $\mathrm{O}$, Pastinen $\mathrm{O}$, Leisola $\mathrm{M}$, von Weymarn $\mathrm{N}$ : Improved xylanase production by Trichoderma reesei grown on L-arabinose and lactose or D-glucose mixtures. Appl Microbiol Biotechnol 2004, 64:353-358.

29. Miettinen-Oinonen A, Paloheimo $M$, Lantto $R$, Suominen $P$ : Enhanced production of cellobiohydrolases in Trichoderma reesei and evaluation of the new preparations in biofinishing of cotton. J Biotechnol 2005, I | 6:305-3 I7.

30. Sandgren M, Shaw A, Ropp TH, Wu S, Bott R, Cameron AD, Ståhlberg J, Mitchinson C, Jones TA: The X-ray crystal structure of the Trichoderma reesei family I 2 endoglucanase 3, Cel I 2A, at I.9 A resolution. J Mol Biol 200I, 308:295-310. 
31. Grishutin SG, Gusakov AV, Markov AV, Ustinov BB, Semenova MV, Sinitsyn AP: Specific xyloglucanases as a new class of polysaccharide-degrading enzymes. Biochim Biophys Acta 2004, 1674:268-28I.

32. Seiboth B, Hartl L, Salovuori N, Lanthaler K, Robson GD, Vehmaanpera J, Penttila ME, Kubicek CP: Role of the bga I-encoded extracellular $\beta$-galactosidase of Hypocrea jecorina in cellulase induction by lactose. Appl Environ Microbiol 2005, 71:85I-857.

33. Poutanen K: An $\alpha$-L-arabinofuranosidase of Trichoderma reesei. J Biotechnol 1988, 7:27|-282.

34. Ilmen M, Thrane $C$, Penttila M: The glucose repressor gene cre I of Trichoderma: Isolation and expression of a full-length and a truncated mutant form. Mol Gen Genet 1996, 25 I:45 I-460.

35. Geysens S, Pakula T, Uusitalo J, Dewerte I, Penttila M, Contreras R: Cloning and characterization of the glucosidase II alpha subunit gene of Trichoderma reesei: a frameshift mutation results in the aberrant glycosylation profile of the hypercellulolytic strain Rut-C30. Appl Environ Microbiol 2005, 7 I:2910-2924.

36. Komili S, Silver PA: Coupling and coordination in gene expression processes: a systems biology view. Nat Rev Genet 2008, 9:38-48.

Publish with Biomed Central and every scientist can read your work free of charge

"BioMed Central will be the most significant development for disseminating the results of biomedical research in our lifetime. "

Sir Paul Nurse, Cancer Research UK

Your research papers will be:

- available free of charge to the entire biomedical community

- peer reviewed and published immediately upon acceptance

- cited in PubMed and archived on PubMed Central

- yours - you keep the copyright 